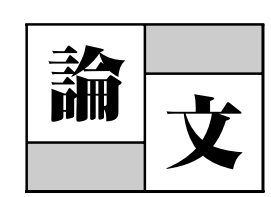

\title{
プラスチック積層体の熱残留応力と反り変形挙動に及ぼす 物性影響因子の熱粘弾性解析
}

\author{
中 村 省 三*1 後 藤 雅 彦*2 -串 崎 義 幸*2
}

\section{Thermo-viscoelastic Analysis of Thermal Residual Stress and Warp Deformation Influenced by Material Properties in Plastic Laminated Beams}

\author{
Nakamura, Shozo*1/Goto, Masahiko*2/Kushizaki, Yoshiyuki*2 \\ Thermal residual stresses and warp deformation of laminated beams constructed from a LSI \\ chip and adhesive, which is the basic structure for plastic composites, were theoretically calcu- \\ lated by using thermo-viscoelastic fundamental equations based on linear-viscoelasticity theory. \\ The results obtained are as follows; \\ (1) Tensile residual stresses at the surface of the chip and compressive residual stresses around \\ the contact area are generated in a LSI chip, while tensile residual stresses are generated in \\ the adhesive material. \\ (2) In order to reduce the interfacial thermal residual stress and warp deformation, the following \\ properties of adhesive materials are desirable ; \\ (i ) high glass transition temperature \\ (ii) low thermal expansion coefficient \\ (iii) low relaxation modulus
}

Key words : Thermo-viscoelastic analysis/Residual stress/Warp deformation/ Semiconductor devices/Plastic composites

\section{1. 緒言}

電子部品に用いる接着剂や LSI チップ，プリント基板 等の接着界面には, 接着剤の硬化収縮や構成材料の熱膨張 差などによって大きな熱残留応力が発生する. 近年, 電子 機器の軽薄短小化により電子部品の小形・薄型化とともに 高密度・高信頼化が強く求められ, 電子部品内部の熱残留 応力や熱変形の低減が重要な課題となっている ${ }^{1) 4)}$. 電子 部品は一般に, 金属, LSI チップ, はんだボール, および 接着剂やアンダーフィルなどのプラスチック材料等で構成 され, これが搭載時のはんだ付け工程や温度サイクル試験 などで熱負荷を受けると, その内部に大きな熱残留応力や 反り変形が生じる。そして，これが原因で接着界面の層間 剥離や材料亀裂，さらには搭載不良などが発生することが

${ }^{* 1}$ 広島工業大学 工学部

広島市佐伯区三宅 2-1-1（ ₹ 731-5193）

Faculty of Engineering, Hiroshima Institute of Technology

2-1-1 Miyake, Saeki-ku, Hiroshima 731-5193, Japan

*2 広島工業大学 大学院

広島市佐伯区三宅 2-1-1（７731-5193）

Graduate Student of Engineering, Hiroshima Institute of

Technology

2-1-1 Miyake, Saeki-ku, Hiroshima 731-5193, Japan 2002.5.29 受理
ある、したがって, 発生する熱残留応力や反り変形挙動を 事前に定量的かつ高精度で予測・評価することは, プラス チック複合構造体の材料・プロセス・構造の最適設計のみ ならず, 高信頼設計手法の構築の上からも極めて重要で ある。

特に，接着剤やアンダーフィル，プリント基板などのプ ラスチック材料は, その熱的・力学的性質が時間と温度に よって著しく変化するいわゆる熱粘弾性挙動を示すことか ら, 発生する熱残留応力や反り変形量を精確に予測・評価 するためには, 既存の弾塑性解析では実態を表現しないと いう問題があり, 熱粘弾性の数值解析法の導入が不可欠と なる ${ }^{5)}$ 〜17).

そこで，これまでに金属とプリント基板，接着剤などか らなるプラスチック複合構造体について, 熱粘弾性解析の 結果を実験結果と比較対比することによって, その妥当 性・有効性を明らかにしている7),15),17).

本報告では, 上記観点から, 電子部品が製造工程や信頼 性試験で負荷される熱によって発生する熱残留応力や反り 変形挙動に及ぼす材料物性因子を評価する目的で, 最も基 本的な LSI チップと接着剤からなる二層積層体を採り上 げた。そして, 種々変化させた接着剤の物性值と積層体内 部に発生する熱残留応力, ならびに反り変形挙動との関係 を熱粘弾性数值解析によって求め, これらに及ぼす材料物 
性因子の定量化と熱残留応力や反り変形を抑制するための 材料設計指針を明らかにした。

\section{2. 熱粘弾性基礎式の誘導}

各種材料から構成される $\mathrm{n}$ 層からなる矩形断面をもつ 多層積層体に発生する積層体内部の熱応力を求める基礎式 を線形粘弾性理論から誘導した。すなわち，積層体に発生 する熱応力は, 厚さ方向の座標 $\mathrm{x}$ と時間 $\mathrm{t}$ の関数となり, これを $\sigma(\mathrm{x}, \mathrm{t})$ とする。そして $\sigma(\mathrm{x}, \mathrm{t})$ は, 構成材料が 線形粘弾性体であり, かつ時間一温度換算則 ${ }^{18)}$ が成立すれ ば，次式で表現できる ${ }^{19), 20)}$.

$$
\begin{aligned}
\sigma(\mathrm{x}, \mathrm{t})=\int_{0}^{\mathrm{t}} \mathrm{E}_{\mathrm{ri}}\left(\mathrm{t}^{\prime}-\tau, \mathrm{T}_{\mathrm{o}}\right) \frac{\mathrm{d}}{\mathrm{d} \tau}\{\varepsilon(\tau) \\
\left.\quad+\kappa(\tau) \cdot \mathrm{x}-\int_{\mathrm{Th}}^{\mathrm{T}(\mathrm{x}, \mathrm{t})} \alpha_{\mathrm{i}}(\mathrm{T}) \mathrm{dT}\right\} \mathrm{d} \tau \\
\mathrm{i}=1 \sim \mathrm{n}
\end{aligned}
$$

ここで， $\mathrm{E}_{\mathrm{ri}}\left(\mathrm{t}\right.$ '， $\left.\mathrm{T}_{\mathrm{o}}\right)$ は $\mathrm{i}$ 層の基準温度 $\mathrm{T}_{\mathrm{o}}$ における貯蔵弾性 率である， $\varepsilon(\mathrm{t})$ は長手方向の伸縮， $\kappa(\mathrm{t})$ は曲率，Th は保 持温度, $\mathrm{T}(\mathrm{x}, \mathrm{t})$ は時々刻々変化する温度分布で, 構成材 料の熱伝導率が温度によって変化せず一定として，一次元 非定常熱伝導の式 ${ }^{21}$ から求められ，厚さ方向の座標 $\mathrm{x}$ およ

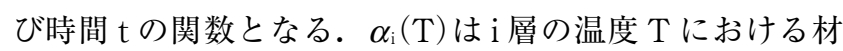
料の線膨張係数である. また，式 $(1)$ の t’, $\tau$ 'は換算時間 であり，これは $\mathrm{i}$ 層の時間－温度移動因子を $\mathrm{a}_{\mathrm{i} \mathrm{To}}(\mathrm{T})$ とすれ ば次式から求められる.

$$
\mathrm{t}^{\prime}=\int_{0}^{\mathrm{t}} \frac{\mathrm{du}}{\mathrm{a}_{\mathrm{iTo}}\{(\mathrm{x}, \mathrm{u})\}}, \mathrm{i}=1 \sim \mathrm{n}
$$

さて，この積層体は冷却過程を通して外部からの拘束が ないことより，力の釣合い式ならびにモーメントの釣合い 式が成立する。

そこで，これらの釣合い式と式(1)，(2)の関係から, 次 式の微分積分方程式が得られる.

$$
\begin{aligned}
& \sum_{\mathrm{i}=1}^{\mathrm{n}} \int_{\mathrm{x}_{\mathrm{i}-1}}^{\mathrm{x}_{\mathrm{i}}} \int_{0}^{\mathrm{t}} \mathrm{E}_{\mathrm{ri}}\left(\mathrm{t}^{\prime}-\tau^{\prime}, \quad \mathrm{T}_{\mathrm{o}}\right) \frac{\mathrm{d}}{\mathrm{d} \tau}\{\varepsilon(\tau) \\
& \left.+\kappa(\tau) \cdot \mathrm{x}-\int_{\mathrm{Th}}^{\mathrm{T}(\mathrm{x}, \tau)} \alpha_{\mathrm{i}}(\mathrm{T}) \mathrm{dT}\right\} \cdot \mathrm{d} \tau \cdot \mathrm{dx}=0 \\
& \mathrm{i}=1 \sim \mathrm{n} \\
& \sum_{\mathrm{i}=1}^{\mathrm{n}} \int_{\mathrm{x}_{\mathrm{i}-1}}^{\mathrm{x}_{\mathrm{i}}} \int_{0}^{\mathrm{t}} \mathrm{E}_{\mathrm{ri}}\left(\mathrm{t}^{\prime}-\tau, \quad \mathrm{T}_{\mathrm{o}}\right) \frac{\mathrm{d}}{\mathrm{d} \tau}\{\varepsilon(\tau)
\end{aligned}
$$

$$
\begin{gathered}
\left.+\kappa(\tau) \cdot \mathrm{x}-\int_{\mathrm{Th}}^{\mathrm{T}(\mathrm{x}, \mathrm{t})} \alpha_{\mathrm{i}}(\mathrm{T}) \mathrm{dT}\right\} \cdot \mathrm{x} \cdot \mathrm{d} \tau \cdot \mathrm{dx}=0 \\
\mathrm{i}=1 \sim \mathrm{n}
\end{gathered}
$$

式 (3)，（4)は，積層体を徐冷，急冷を問わず冷却した場 合に生ずる熱応力を求める基礎式である.すなわち, 式(3), (4) を満足する $\varepsilon(\mathrm{t}), \kappa(\mathrm{t})$ を求めることができれば, 式 (1) から時々刻々変化する熱応力分布 $\sigma(\mathrm{x}, \mathrm{t})$ を求めること ができる。そして $\sigma(\mathrm{x}, \mathrm{t}), \varepsilon(\mathrm{t}), \kappa(\mathrm{t})$ は冷却後に時間 が十分経過し, 積層体全体が冷却温度に一様になった状態 においてもなお残留する場合に，これらは残留応力 $\sigma_{\mathrm{r}}(\mathrm{x})$, 残留伸縮 $\varepsilon_{\mathrm{r}}$, 残留曲率 $\kappa_{\mathrm{r}}$ となる.

\section{3. 積層体の熱粘弾性解析}

\section{1 積層体の形状}

実際の半導体パッケージは複雑構造であるが，ここでは その最も基本的構成として LSI チップと接着剤からなる 二層積層体を解析対象とし, その形状を図 1 に示す. ここ で，特に，積層体の熱残留応力および反り変形挙動に大き く影響を及ぼし，かつその熱的・機械的性質が温度と時間 に大きく影響される接着剤をLSI チップの相手材として 採り上げた. そして, 積層体の厚さは LSI チップが $0.3 \mathrm{~mm}$, 接着凨を $0.2 \mathrm{~mm}$ とした。

\section{2 解析に用いた材料物性値}

積層体を構成する材料の熱的・機械的性質を表 1 に示す. ここで，接着剤は有機材料であり，その物性值は温度と時 間の影響を大きく受ける熱粘弾性挙動を示す材料である.

この代表的な接着剤について, 低温から高温までの広い 温度範囲で周波数を $0.1 ， 1 ， 10$, および $100 \mathrm{~Hz}$ の 4 種類 に変化させて動的粘弾性特性を測定した。測定には(株)ユー

\begin{tabular}{|c|c|c|c|c|c|c|c|c|}
\hline Propatie & $\begin{array}{c}\text { Thermal } \\
\text { conductivity }\end{array}$ & Specific heat & Density & $\begin{array}{c}\text { Glass transition } \\
\text { temperature } \\
\mathrm{Tg} \\
\end{array}$ & \multicolumn{2}{|c|}{$\begin{array}{l}\text { Thermal } \\
\text { expansion } \\
\text { coefficient }\end{array}$} & \multicolumn{2}{|c|}{$\begin{array}{l}\text { Relaxation } \\
\text { modulus }\end{array}$} \\
\hline & \multirow{2}{*}{$(\mathrm{W} / \mathrm{mK})$} & \multirow{2}{*}{$(\mathrm{kJ} / \mathrm{kgK})$} & \multirow{2}{*}{$\left(\mathrm{kg} / \mathrm{m}^{3}\right)$} & \multirow{2}{*}{$\left({ }^{\circ} \mathrm{C}\right)$} & \multicolumn{2}{|c|}{$\left(10^{-6} / \mathrm{K}\right)$} & \multicolumn{2}{|c|}{$(\mathrm{GPa})$} \\
\hline Materials & & & & & $\mathrm{T} \leqq \mathrm{Tg}$ & $\mathrm{Tg}<\mathrm{T}$ & $\mathrm{T} \leqq \mathrm{Tg}$ & $\mathrm{Tg}<\mathrm{T}$ \\
\hline LSI Chip & 148 & 0.799 & 2330 & - & \multicolumn{2}{|c|}{3.60} & \multicolumn{2}{|c|}{192} \\
\hline Adhesive & 0.186 & 1.42 & 1220 & $90.0^{* 1}$ & $88.0^{* 2}$ & $217^{* 2}$ & $3.40^{* 3}$ & $0.03^{* 3}$ \\
\hline
\end{tabular}
ビーエム製の Rheogel-E 4000 を用いた。この測定結果を 基準温度 $\mathrm{T} 。$ の下で換算対数時間軸上にプロットし, 貯蔵 弾性率のマス夕曲線22 を作成した. その結果を図 2 に示す. この図からわかるように，接着剤の貯蔵弾性率は極短時間

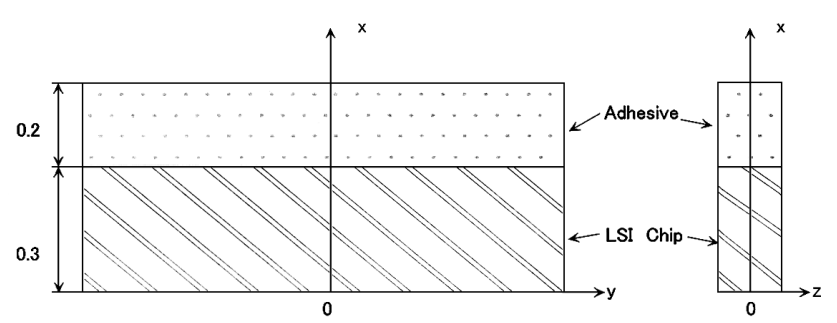

Flg. 1 Shape and coordinate of two layer laminated beam

Table 1 Thermal and mechanical characteristics of cunstitutive materials

*1: Reference Fig. 4 *2: Reference Fig. 5 *3: Reference Fig. 6 


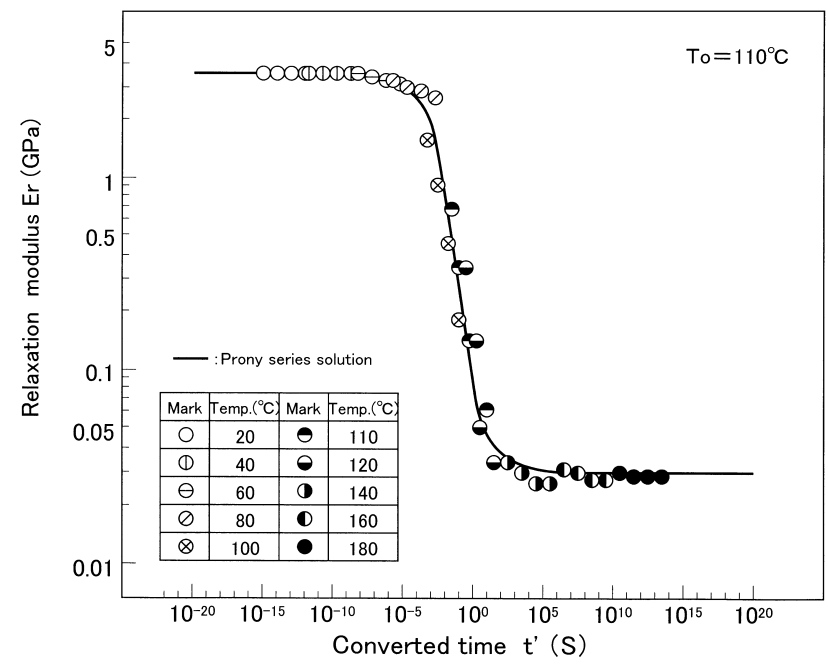

Fig. 2 Master curve of relaxation modulus for adhesive

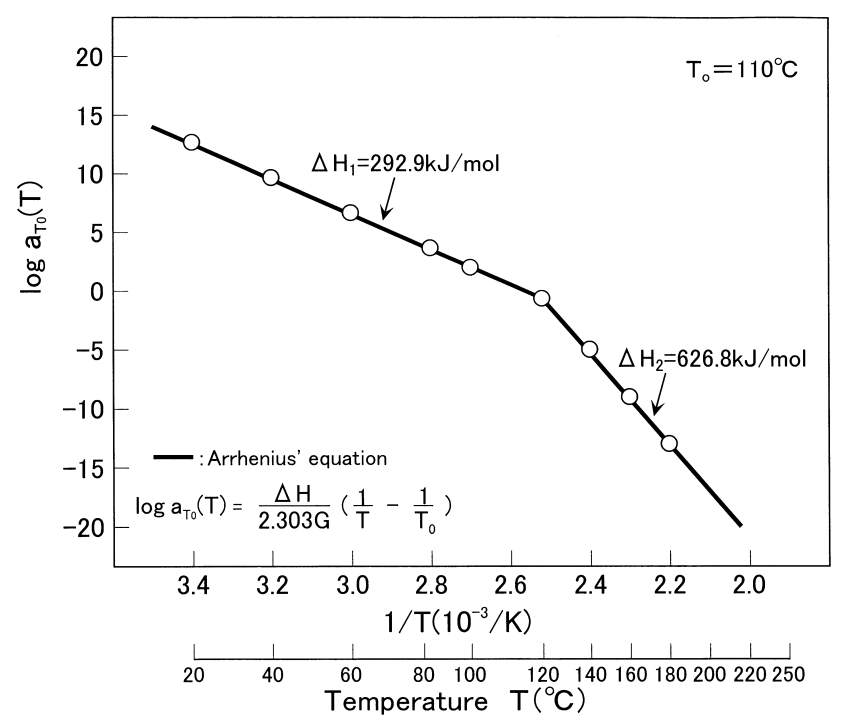

Flg. 3 Time-temperature shift factor $\mathrm{a}_{\mathrm{T}_{\mathrm{o}}}(\mathrm{T})$ for adhesive

から極長時間にわたって一本の滑らかなマスタ曲線が得ら れる。また，このマス夕曲線を作成する際の時間－温度移 動因子は図 3 に示すように, 高温部と低温部とで活性化工 ネルギ $\Delta \mathrm{H}$ の異なる 2 本のアレニウス式で近似することが できた。このことから，ここで採り上げた接着剤は著しい 熱粘弾性挙動を示し，かつ，時間－温度換算則が成立する 材料であることがわかった。

ここで, 積層体の熱応力と反り変形挙動に大きく影響を 及ぼすと考えられる接着剤の物性に着目した。すなわち， 接着剂の(1)ガラス転移温度, (2)線膨張係数, (3)貯蔵弾性率 の代表的な 3 種類の物性を影響因子と考え, それぞれ図 4 〜 図 6 に示す物性パラメータサーベイを行った。

\section{3 熱粘弾性解析の方法}

図 1 に示す積層体について, 熱負荷を与えた場合に生じ る熱応力および反り変形挙動を熱粘弾性解析により求めた. 解析に当たり, 温度条件は一般の製造プロセスで用いられ る接着温度 $180^{\circ} \mathrm{C}$ から $20^{\circ} \mathrm{C}$ の場合を採り上げた。また, 解析に用いた接着剂の物性值は前述の各種パターンを有し

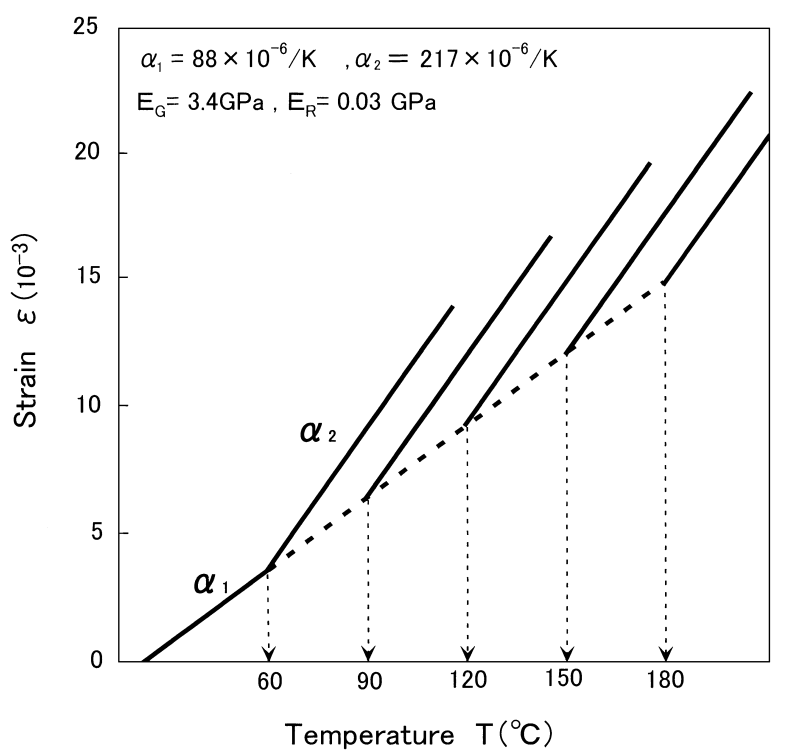

Fig. 4 Patterns of glass transition temperature for adhesive

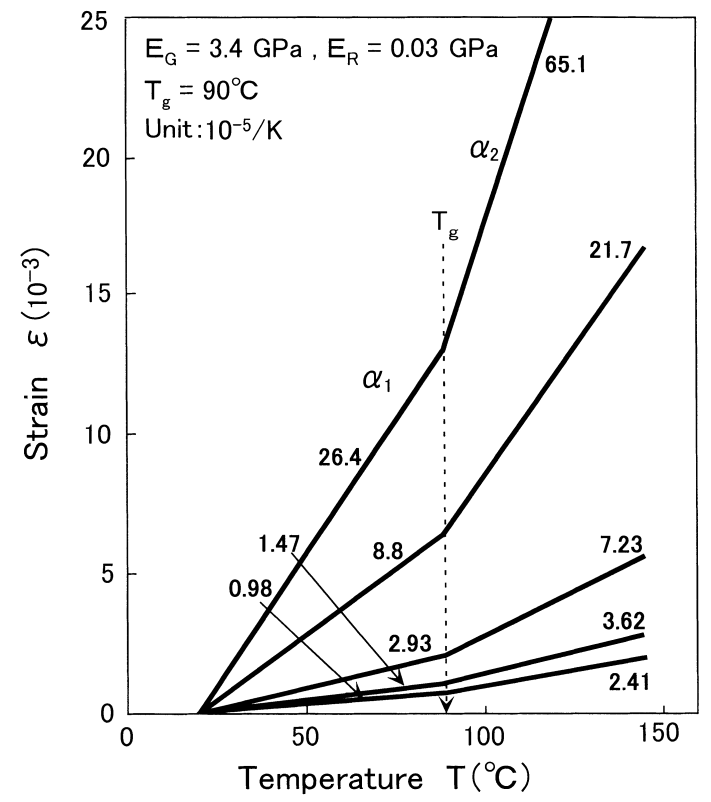

Fig. 5 Patterns of thermal expansion coefficient for adhesive

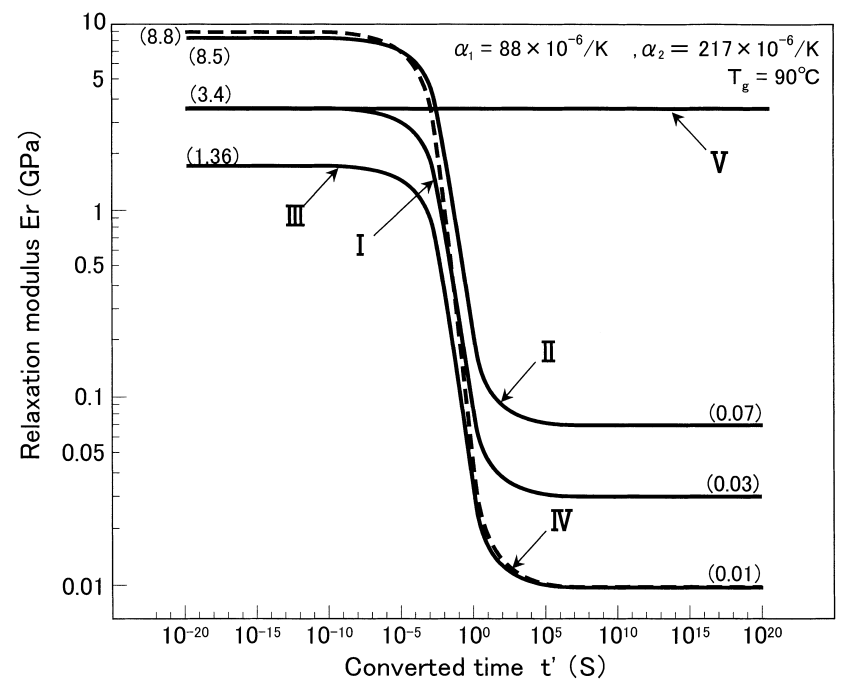

Fig. 6 Patterns of relaxation modulus for adhesive 


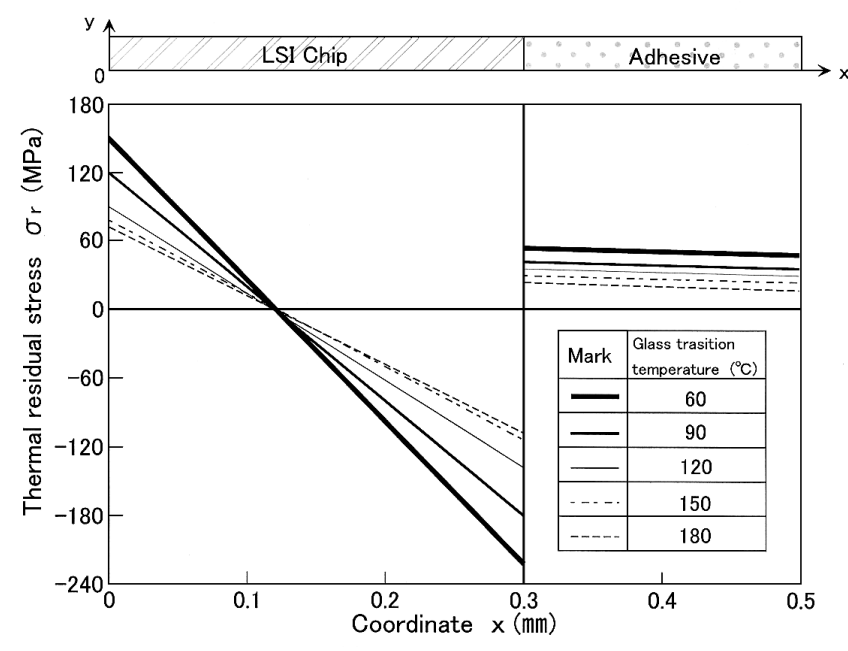

Fig. 7 Relationship between glass transition temperature and thermal residual stress

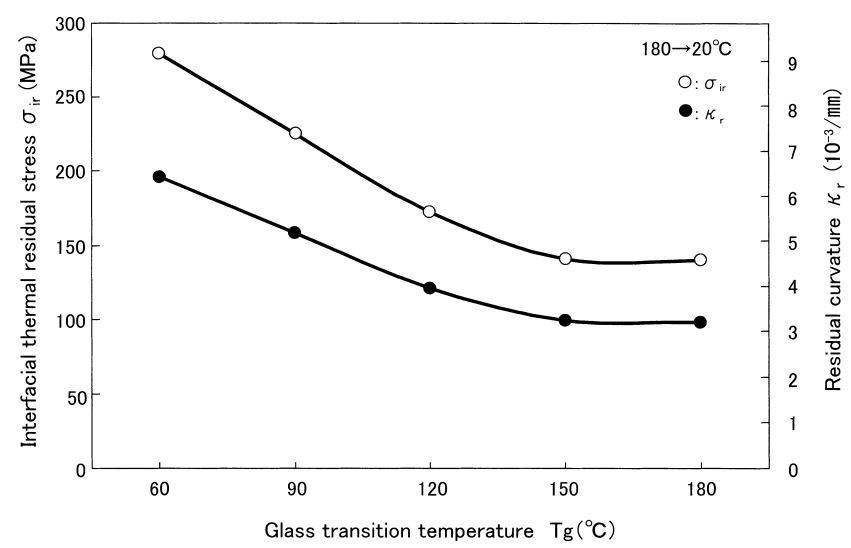

Fig. 8 Relationship between glass transition temperature and interfacial thermal residual stress, residual curvature

た值をパラメータとして，その他については表 1 に示す物 性值を用いた。また積層体を空気冷却する際の熱伝達率は, 予備実験の結果から $46 \mathrm{~W} / \mathrm{m}^{2} \mathrm{~K}$ の值を採用した.

\section{4. 結果と考察}

\section{1 ガラス転移温度依存性}

接着剤のガラス転移温度が積層体の熱残留応力や反り変 形挙動に大きく影響を及ぼすため，ここでは，図 4 に示す ように接着剤のガラス転移温度を $60^{\circ} \mathrm{C}, 90^{\circ} \mathrm{C}, 120^{\circ} \mathrm{C}, 150^{\circ} \mathrm{C}$ および $180^{\circ} \mathrm{C}$ の 5 パターンに変化させて熱残留応力分布を 解析した。 その結果を図 7 に示す.

ここで，貯蔵弾性率の值は，低温時の $3.4 \mathrm{GPa}$ から高 温時の $0.03 \mathrm{GPa}$ の範囲で変化させ, 線膨張係数の值は, ガラス転移温度以下の領域で $88 \times 10^{-6} / \mathrm{K}$, ガラス転移温 度以上で $217 \times 10^{-6} / \mathrm{K}$ とした。

図 7 から, LSI チップ内部では表面 $(\mathrm{x}=0)$ 近傍の引張 の応力から界面 $(\mathrm{x}=0.3 \mathrm{~mm})$ 近傍の圧縮の応力へと直 線的に分布し, 一方, 接着剂内部では引張の残留応力が発 生していることがわかる.

ここで，LSI チップと接着剤の接着界面において，LSI チップ側に生じる残留応力と接着剤側に生じる残留応力と の差を層間熱残留応力と表示し, これが界面接着剥離の原

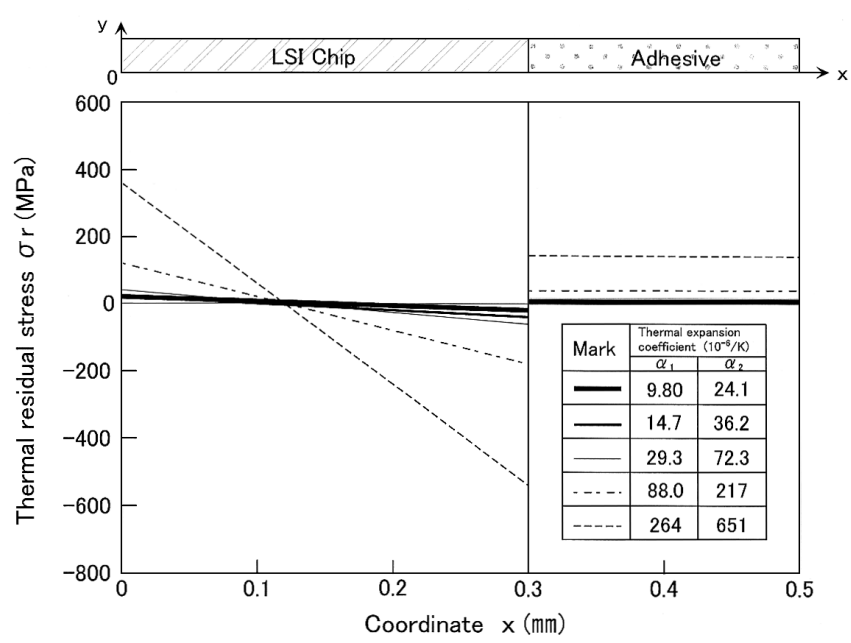

Fig. 9 Relationship between thermal expansion coefficient and thermal residual stress

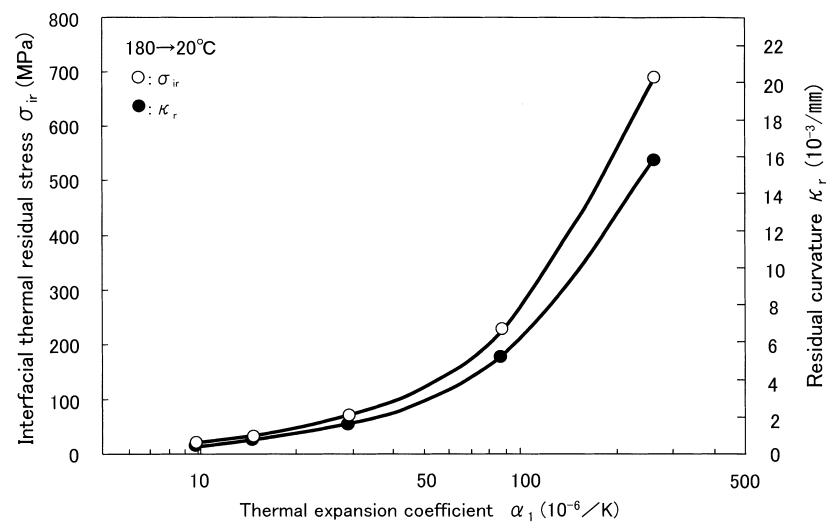

Fig. 10 Relationship between thermal expansion coefficient and interfacial thermal residual stress, residual curvature

因となる残留せん断応力に相当するものと考えられる。そ こで，この層間熱残留応力および残留曲率とガラス転移温 度との関係を図 8 に示す。この図から，ガラス転移温度が 高くなると発生する層間熱残留応力と残留曲率は減少する ことがわかる．この理由は，ガラス転移温度が高くなると， 接着剤のガラス転移温度以下の線膨張係数 $\left(88 \times 10^{-6} / \mathrm{K}\right)$ が占める温度領域が増大するためである。このことから， 接着剂のガラス転移温度を高くする方が積層体の界面接着 剥離の防止のみならず反り変形を抑制する上からも望まし いと言える。

\section{2 線膨張係数依存性}

接着剤の線膨張係数が積層体に発生する熱残留応力と反 り変形挙動に及ぼす影響を検討した。ここで，接着剤の線 膨張係数はガラス転移温度以下で $88 \times 10^{-6} / \mathrm{K}$ ，ガラス転 移温度以上で $217 \times 10^{-6} / \mathrm{K}$ を基準とし, 図 5 に示す 5 パ ターンについて熱残留応力との関係を求め, 図 9 に示す.

ここで, 貯蔵弾性率は低温時の $3.4 \mathrm{GPa}$ から高温時の 0.03 $\mathrm{GPa}$ の範囲で変化させ, ガラス転移温度は $90^{\circ} \mathrm{C}$ 一定とし た.この図から, LSI チップ内部では表面 $(\mathrm{x}=0)$ 近傍の 引張の応力から界面 $(\mathrm{x}=0.3 \mathrm{~mm})$ 近傍の圧縮の応力へ と直線的に分布し, 接着剤内部では引張の残留応力が発生 することがわかる。 


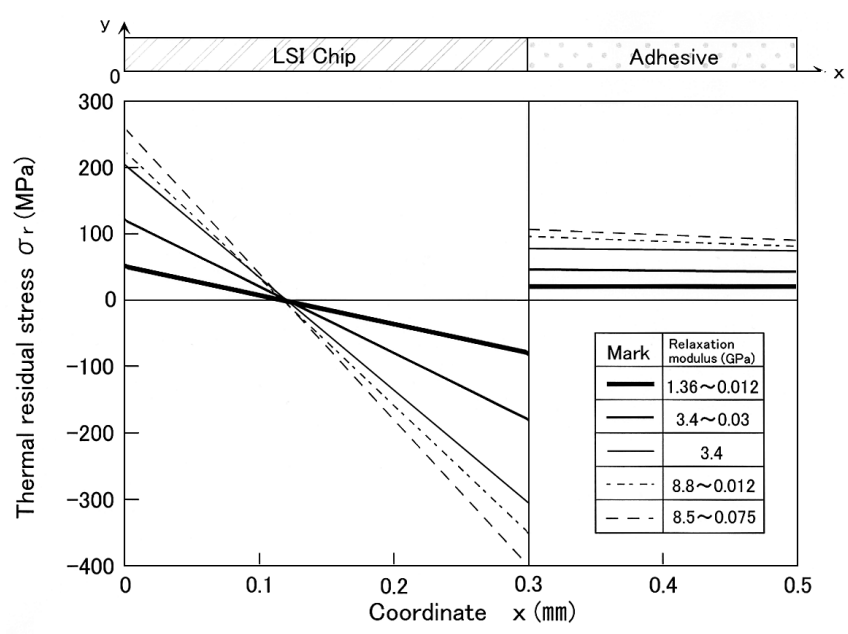

Fig. 11 Relationship between relaxation modulus and thermal residual stress

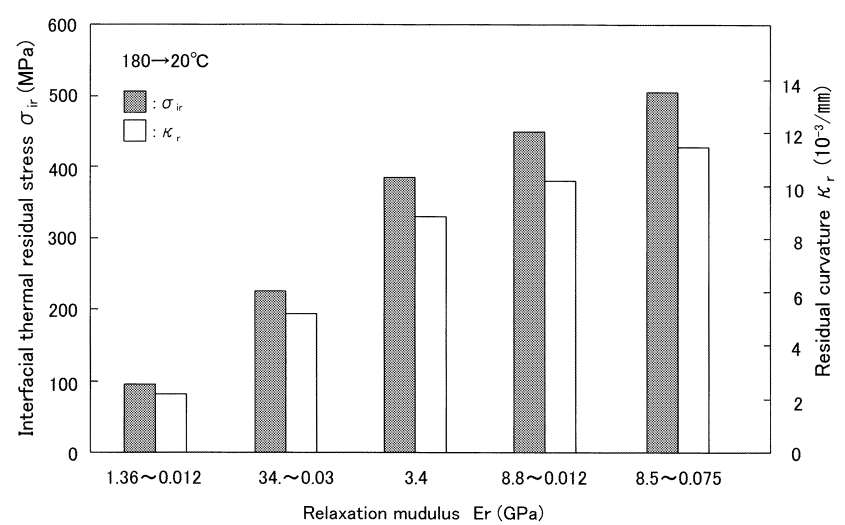

Fig. 12 Relationship between relaxation modulus and interfacial thermal residual stress, residual curvature

図 10 に接着剂の線膨張係数の各種パターンと層間熱残 留応力および残留曲率の解析結果を示す. この図から, 発 生する層間熱残留応力ならびに残留曲率は, 線膨張係数の 值が大きくなると増加する傾向がある．このことから，界 面接着剥離の防止と反り変形の抑制の点で接着剤の線膨張 係数を小さくする，すなわち接着剤の線膨張係数の值を相 手材である LSI チップの線膨張係数の值に近づける方が 有利であると言える.

\section{3 貯蔵弾性率依存性}

前節に続いて，ここでは貯蔵弾性率が熱残留応力や反り 変形挙動に及ぼす影響を調べるため, 貯蔵弾性率のパター ンを図 6 に示す 5 種類変化させて熱粘弾性解析した。すな わち，最も一般的な接着剤の值をもつものを基準（3.4〜 $0.03 \mathrm{GPa}$ : パターン I ) とし, 次いで基準より 2.5 倍大 きな值をもつもの $(8.5 \sim 0.07 \mathrm{GPa}$ ：パターン II ), 基準 の $1 / 3$ 程度の小さい值をもつもの $(1.36 \sim 0.01 \mathrm{GPa}$ ：パ ターン III ), 変動幅が大きいもの $(8.8 \sim 0.01 \mathrm{GPa}$ ：パター ン IV)，および貯蔵弾性率の温度依存性が認められないも の $(3.4 \mathrm{GPa}$ 一定 : パターンV $)$ の 5 パターンである.な お，このときの線膨張係数の值は, ガラス転移温度以下の 領域で $88 \times 10^{-6} / \mathrm{K}$ ，ガラス転移温度以上で $217 \times 10^{-6} / \mathrm{K}$ とし，ガラス転移温度は $90^{\circ} \mathrm{C}$ 一定とした。

図 11 に 5 種類の貯蔵弾性率のパターンに対する熱残留
応力分布を示す。この図から, LSI チップ内部では表面 $(\mathrm{x}$ $=0 ）$ 近傍の引張の応力から界面 $(\mathrm{x}=0.3 \mathrm{~mm})$ 近傍の圧 縮の応力へと直線的に分布し, 接着剤内部では引張の残留 応力が発生することがわかる. また, 図 12 に各種貯蔵弾 性率のパターンに対する層間熱残留応力と残留曲率の関係 を示す.この図で, 基準となるパターン I と他のパターン について比較すると, 基準より大きな值を想定したパター ン II では, 層間熱残留応力および残留曲率ともに 2.2 倍程 度大きくなる。また，基準より小さい值のパターン III では， パターン I に比べ 0.5 倍程度になる. 次いで, 変動幅が大 きいパターン IVは，パターン I に比べ 2 倍程度大きくなる. また, 貯蔵弾性率を一定としたパターンVは, パターン I に比べ 1.5 倍程度大きな值を示す.このことから, 低温か ら高温の全領域においていずれも貯蔵弾性率の值が小さい 接着剤を採用する方が, 相手材である LSI チップの挙動 に対する影響力が小さくなり，影響界面接着剥離と反り変 形の抑制の点で有利であることがわかる.

\section{5. 結言}

プラスチック複合構造体の最も基本的な構成である LSI チップと接着剤からなる二層積層体を対象に, 熱負荷を与 えた場合に発生する熱残留応力と反り変形挙動を, 接着剤 の物性との関係で熱粘弾性解析し, 以下の結論を得た.

（1）積層体を製造温度の $180^{\circ} \mathrm{C}$ から室温まで冷却した際に 発生する熱残留応力分布は, LSI チップ内部では表面 近傍の引張応力から界面近傍の圧縮応力へと直線的に 分布する. 一方, 接着剂内部では引張の残留応力分布 となる。

（2）界面接着剥離の原因となる層間熱残留応力や反り変形 は，相手材である LSI チップの物性と相互に関係す る、これらを抑制するためには，本研究の範囲におい て, 接着剤の物性としてガラス転移温度は最も高い $180^{\circ} \mathrm{C}$, 線膨張係数はガラス転移温度以下で $9.8 \times 10^{-6}$ $/ \mathrm{K}$, ガラス転移温度以上で $24.1 \times 10^{-6} / \mathrm{K}$, 貯蔵弾性 率は $1.36 〜 0.01 \mathrm{GPa}$ の組合せが望ましい.

なお，これらの物性值については製造プロセス上の問題 や相手材の物性值とも密接に関係するので, その最適值に ついては総合的に決定する必要がある.

\section{参 考 文 献}

1 ) Taketani, N., Hatano, K., Sugimoto, H., Yoshioka, O. and Murakami, G. : ISHM, Proceeding, 594 (1996)

2 ) 村上 元：エレクトロニクス実装学会誌，1(1), 19 (1998)

3 ）酒見省二, 野田和宏：エレクトロニクス実装学会誌, 2 (3)，236（1999）

4 ) 竹村賢三, 永井 朗, 渡辺伊津夫 : エレクトロニクス 実装学会誌，2(2)，99（1999）

5 ) 村上 元, 中村省三, 御田 護, 宮野 靖: エレクト ロニクス実装学会誌，3(1)，34（2000）

6 ) Murakami, G., Mita, M., Nakamura, S., Ueno, K. and Nakamura, K. : Chip Scale Review, 2(5), 55 (1998)

7 ) 中村省三, 村上 元, 井坂和博, 上野恵尉, 中村敬一： エレクトロニクス実装学会誌，2(4)，291（1999） 
8 ）中村省三, 河野 務, 御田 護, 上野恵尉：プラスチッ ク成形加工学会講演論文集（1998）

9 ）中村省三, 串崎義幸, 村上 元, 木戸光夫 : エレクト ロニクス実装学会誌，5(4) (2002)

10）中村省三，後藤雅彦，串崎義幸，木戸光夫：エレクト ロニクス実装学会誌，5(7) (2002)

11）中村省三, 串崎義幸, 後藤雅彦, 大橋和彦, 木戸光夫 : エレクトロニクス実装学会誌，6(1) (2003)

12）河田裕志, 池上晧三：日本機械学会論文集, 56A, 2471 (1990)

13）大堀雅志，佐藤千明，池上晧三：材料，43，18(1994)

14）中村省三, 篠田忠夫, 金田愛三, 宮野 靖：日本機械 学会講演論文集，864(2)，28（1986）

15）中村省三, 宮野 靖, 杉森 勝, 金田愛三：日本機械
学会論文集，53A，1813（1987）

16) Nakamura, S., Miyano, Y., Sugimori, S. and Kaneda, A. : JSME International Journal, 31, 126 (1988)

17）中村省三, 長谷部昭雄, 芹沢弘二, 高坂 崇, 春田 亮：高分子論文集，51，806（1994）

18) Williams, M. L., Landle, R. F. and Ferry, J. D. : J. Am. Chem. Soc.77, 3701 (1955)

19）牟岐鹿桜：日本機械学会誌，64，34（1961）

20）國尾 武：固体力学の基礎, 東京, 24（1983）, 培風 館

21）川下研介：熱伝導論，東京，96（1966），オーム社

22）中川鶴太郎：レオロジー，東京，220（1983）, 岩波全 書 